
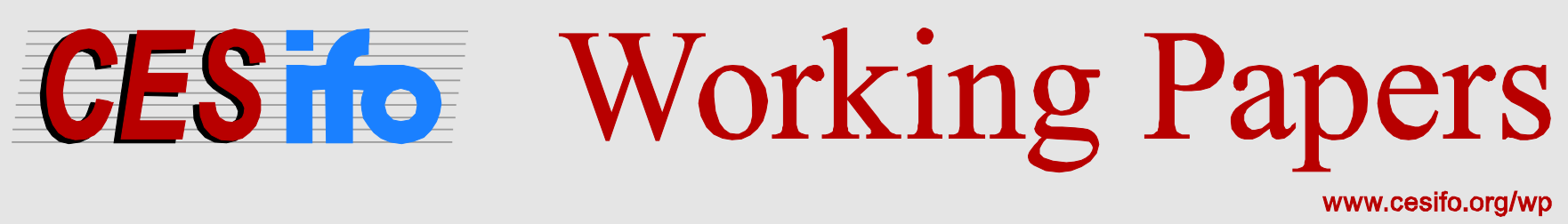

\title{
The Efficiency Costs of Dividend Taxation with Managerial Firms
}

\author{
Marko Koethenbuerger \\ Michael Stimmelmayr
}

\section{CESIFO WORKING PAPER NO. 5569 \\ CATEgORY 1: PUBlic FinANCE \\ OCTOBER 2015}

Presented at CESifo Area Conference on Public Sector Economics, April 2015

\author{
An electronic version of the paper may be downloaded \\ - from the SSRN website: \\ - from the RePEc website: \\ - from the CESifo website: \\ wWw.SSRN.com \\ Www.RePEc.org \\ www.CESifo-group.org/wp
}




\title{
The Efficiency Costs of Dividend Taxation with Managerial Firms
}

\begin{abstract}
The paper analyzes the efficiency costs of dividend taxation in an effort-based corporate agency model in which non-verifiable managerial effort enhances taxable profits. We show that investment changes following a rise in dividend taxes might not be sufficient to infer the efficiency cost of dividend taxation as well as the financing regime of the firm that underlies the investment response, in contrast to insights from previous literature. We provide a testable implication to infer the mode of investment finance from investment responses. Furthermore, we show that imposing income tax on managerial incentive pay is welfare equivalent to a general dividend tax. Finally, we relate the results to recent empirical findings in the literature on dividend taxation.
\end{abstract}

JEL-Codes: H250, D210.

Keywords: dividend taxation, managerial effort, corporate governance, tax on incentive pay, managerial firms.

\author{
Marko Koethenbuerger \\ ETH Zurich / Department of Management, \\ Technology and Economics \\ Leonhardstr. 21 \\ Switzerland - 8092 Zurich \\ koethenbuerger@kof.ethz.ch
}

\author{
Michael Stimmelmayr \\ ETH Zurich / Department of Management, \\ Technology and Economics \\ Leonhardstr. 21 \\ Switzerland - 8092 Zurich \\ stimmelmayr@kof.ethz.ch
}

We are grateful to seminar and conference participants in Oslo (OFS Workshop on 'Taxing capital income: the role of business and personal taxation', 4-5 April 2014), in Munich (CESifo PSE conference, 16-18 April 2015), in Dublin (IIPF annual meeting, 20-23 August 2015) and in Mannheim (EEA annual congress, 24-27 August, 2015, and ZEW MaTaX conference, 1-2 October, 2015). In particular, we are grateful for the valuable comments made by Annette Alstadsæter, Vidar Christiansen, Dhammika Dharmapala, Andreas Hauer, Andrea Schneider, and Vesa Kanniainen. Financial support through a grant from the European Policy Research Network (EPRN grant \# 30570) and the German Science Foundation (DFG STI 619/1-1) is gratefully acknowledged. 


\section{Introduction}

The issue of how dividend taxes affect firm behavior has generated considerable interest in public economics and among policy makers alike. The central issue is how dividend taxes influence dividend pay-outs and firm investments and how these responses shape the efficiency effects that follow from the taxation of dividend income (Auerbach, 2002). Recent empirical evidence points to the role of corporate agency conflicts in the way in which dividend taxes influence firm behavior. For instance, firms with more powerful principals, as indicated by the extent of taxable institutional ownership or the representation of independent shareholders on the board of directors, increased dividend payments more strongly after the 2003 US dividend tax cut (Chetty and Saez, 2005). ${ }^{1}$ Furthermore, executives with larger managerial stock ownership have been found to be more likely to increase dividend distributions, consistent with managers acting in their own interests (Brown et al., 2007; Blouin et al., 2011). The empirical findings suggest that agency-related dividend responses influence investment behavior through their impact on corporate cash flow, thereby inducing investment responses that are unique to agency models (Becker et al., 2013; Chetty and Saez, 2010).

The results point to the usefulness of linking traditional efficiency analysis of dividend taxation with corporate agency models to provide a more coherent understanding of firms' responses to dividend taxation and the efficiency effects associated therewith. Using a corporate agency model we show that investment changes following a rise in dividend taxes might not be sufficient to infer the efficiency cost of dividend taxation as well as to link uniquely the investment responses to the financing regime of the firm, in contrast to two main findings established in previous work (Auerbach, 2002; Chetty and Saez, 2010). Indeed, we find that dividend tax incurs an efficiency cost even when dividend taxes stimulate investments, which enhances efficiency in our setting, and this might happen when both retained earnings and new equity issues finance investments at the margin.

We set up a corporate agency model in which managerial effort influences production. The model builds on the general insight that managerial effort determines the way in which inputs are combined in production and thereby the effectiveness of other inputs such as physical in-

\footnotetext{
${ }^{1}$ In a related manner, Jacob et al. (2015) show that the sensitivity of dividend policy to owners' tax preferences phases out as the number of owners increases, suggesting that managers pursue private agendas different to satisfying shareholder interests as ownership becomes more dispersed. Exploiting the 2006 rise in dividend taxes in Norway, Berzins et al. (2014) find a strong negative effect of dividend taxes on pay-outs, and that a pre-existing agency conflict between shareholders and the management moderates the tax effect.
} 
vestment (Tirole, 2006). For instance, managerial effort might increase output through the screening of ex-ante imperfectly known investment projects. Alternatively, effort might not only be directed toward capital productivity. It might also enhance output through organizational changes the implementation of which requires managerial effort and allows employees to be more productive. ${ }^{2,3}$ Managerial effort is non-verifiable and thus cannot be controlled perfectly through contractual arrangements. As the return on managerial effort provision accrues to shareholders through higher firm valuations, shareholders might link the managerial wage to firm performance to incentivize the manager to exert more effort in overseeing the firm's activities, and thereby align the interests of the manager and shareholders.

In this setting, we show that dividend taxes influence investment behavior depending on how effort interacts with investments in production. For instance, the complementarity of the two inputs implies a negative investment response to dividend taxes. The finding holds independently of whether marginal investments are financed by retained earnings or external equity. This contrasts with the traditional tax efficiency analysis, which builds on the new view and old view of dividend taxation. The different views predict that dividend taxes are neutral for the investment behavior of firms that use retained earnings as the marginal source of funds (new view) and will downwardly distort the investments of those firms that use equity injections at the margin (old view). Our findings have implications for linking investment responses to economic efficiency. In particular, the investment response in the effort-based corporate agency model might be observationally equivalent to the investment response under the old view, although retained earnings ultimately finance investments at the margin. This finding goes against the two well-established views on deducing a firm's financing behavior from the empirically observed sensitivity of investments to dividend taxes and inferring the efficiency effects of dividend taxation from this information. The paper proposes a testable implication to infer the firms' financing behavior from investment responses in corporate agency models. Dividend taxes and the sharing parameter in the equity-based incentive contract influence a firm's investment behavior in the same way when retained earnings are the marginal source of funds. However, dividend taxes affect

\footnotetext{
${ }^{2}$ See, e.g., Bloom and Van Reenen (2010) for an overview of the literature on the relation between management practices (such as human resource management and information technology management) and firm performance. Higher firm productivity due to better management practices might reflect differences in managerial quality, as in Lucas (1978). See Guner et al. (2015) for a quantification of how managerial quality shapes productivity differences across firms and countries. Estimating the value of managers for firms, Bennedsen et al. (2010) show that managerial input is an important determinant of firm performance.

${ }^{3}$ In the model we use a reduced-form representation of the relation between output and effort, thereby capturing various structural models of output-enhancing managerial effort choices.
} 
investment incentives more strongly than the sensitivity of managerial pay to performance when the firm uses equity injections at the margin. Interestingly, this testable hypothesis is robust to a wide range of corporate agency models, including effort-based agency models (used in this paper) and models of free cash flow (Jensen, 1986). ${ }^{4}$

In the agency model at hand, dividend taxation incurs efficiency costs with both sources of investment finance, and these costs generally depend on the responses of effort and investment to dividend taxes. However, in the case of an Allowance for Corporate Equity (ACE) system and an R-based cash flow system, two frequently discussed and probed variants of a corporate tax system, ${ }^{5}$ the efficiency effects solely follow from effort responses, despite the tax-induced investment response. Furthermore, in the absence of these two types of corporate tax systems, dividend taxes might still incur an efficiency cost even when they increase investment, which in isolation enhances efficiency in our setting. As such, unlike existing models of dividend taxation, investment responses are not sufficient to infer the magnitude and sign of the efficiency implications of dividend taxes.

The model allows us to address the frequently voiced issue of levying a separate tax on equitybased incentive pay. Equity-based incentive pay receives differential tax treatment compared to general income in some countries (Hall and Liebman, 2000) and the issue of using such a tax scheme has regained momentum in recent tax policy discussions. Theoretically, a differential tax treatment might correct a tendency to under- or over-incentivize managers (Benabou and Tirole, 2015; Besley and Ghatak, 2013), or might limit socially wasteful bargaining effort by managers (Piketty et al., 2014). It transpires that imposing a separate income tax and a dividend tax on all shareholders is equivalent in terms of their effects on firm behavior and efficiency. This result might be surprising given that the two taxes are imposed on different sets of individuals and thus might be expected to have a different impact on their decisions. The reason for the equivalence in this result is that shareholders, who set the managerial wage, become residual claimants and perceive the two instruments as perfect substitutes. ${ }^{6}$ Most notably, the incentive contract they offer to managers changes with each of the two instruments in an identical way. As a consequence, the contract-induced managerial effort and investment choice coincide with

\footnotetext{
${ }^{4}$ In these models, shareholders and managers disagree on the amount of cash flow that is distributed to shareholders. Empire-building managers have a preference for keeping cash in the firm, which allows them to finance projects earning low returns which otherwise would not been funded by shareholders or equity markets.

${ }^{5}$ For a discussion, see Auerbach et al. (2010) for instance.

${ }^{6}$ As shown later on, the equivalence results extends to other forms of wage determination in which shareholders do not have all the bargaining power.
} 
the two tax instruments. Compared to a special tax on manager equity-based income, a general dividend tax has the potential to achieve identical efficiency effects.

\subsection{Literature Review}

The literature on the effects of dividend taxation largely centers on the old view and new view of dividend taxation (Sinn, 1987; Auerbach, 2002). The two alternative views draw on different assumptions about the source of investment funds. Under the old view, developed in Poterba and Summers (1985), the source of funds is a new equity issue. Dividend distributions are taxed while capital injections do not receive a subsidy. ${ }^{7}$ The asymmetric tax treatment introduces tax distortions and reduces firm investments. Under the new view, developed in King (1974), Auerbach (1979), and Bradford (1981), the source of investment funds is retained earnings. Retaining profits to finance investments implies only a re-timing of dividend taxes, which renders dividend taxes neutral for investment behavior. ${ }^{8}$ Empirical analyses of the relevance of the two views include Poterba and Summers (1985), Poterba (2004), and Auerbach and Hasset (2002), among others. The literature derives two competing views from a theoretical framework in which corporate agency issues are not considered.

Unlike traditional efficiency analysis in public finance, Kanniainen (1999) sets up a free cash flow model of firm behavior in which managers try to build an empire and invest resources differently to shareholder preferences, analyzing the role of dividend taxes for investments therein. More recently, Chetty and Saez (2010) resorted to a free-cash flow model to explain firm responses after the 2003 U.S. dividend tax cut relating them to efficiency effects. ${ }^{9}$ In this setting, dividend taxes do not change incentives to invest productively provided retained earnings finance marginal investments. This is consistent with the new view of dividend taxation. Nevertheless, total investment outlays increase after a tax hike because dividend taxes incentivize managers to expand the empire and invest resources unproductively rather than making distributions to shareholders. Such a positive investment response is consistent with recent findings in Becker et al. (2013). ${ }^{10}$ In the effort-based agency model analyzed in this paper, all investments are

\footnotetext{
${ }^{7}$ See Lindhe and Södersten (2014) for a refined treatment of the imperfect tax deductibility of the costs of investment finance that underlies the old view of dividend taxation.

${ }^{8}$ More precisely, tax neutrality under the new view applies even more broadly provided the source of funds and use of funds are the same. Thereby, the tax treatment is also the same and neutral for investment decisions.

${ }^{9}$ There is an evolving, albeit small, body of literature on the role of corporate taxes in agency models. For instance, see Kanniainen and Södersten (1994), Crocker and Slemrod (2005), Desai and Dharmapala (2006), Desai et al. (2007), Chetty and Saez (2010), and Koethenbuerger and Stimmelmayr (2014).

${ }^{10}$ Related contributions on dividend taxation include Gordon and Dietz (2009) and Korinek and Stiglitz (2009).
} 
productive and managers are not empire builders. Yet, the model likewise predicts a positive investment response to higher dividend taxes, provided effort and investment are substitutes in production. This corroborates the finding that positive investment responses to dividend taxes are consistent with optimal corporate behavior once frictions within the firm are accounted for.

Unlike the free cash flow model, the investment response of firms that use retained earnings at the margin is not limited in sign to explain anomalies (based on traditional analysis) in investment responses to dividend taxation. Indeed, the model might also predict negative investment responses, which are frequently documented in empirical analyses, both when retained earnings and new share issues are used as the marginal source of funds. A negative investment response is consistent with the conventional views of dividend taxation and a model of free cash flow only when the firm uses new share issues to finance marginal investments (Poterba and Summers, 1985; Chetty and Saez, 2010). This suggests that the informational value of observing a negative investment response is more limited than the two conventional views of dividend taxation, as well as a model of free cash flow, imply. As explained above, the paper provides a testable hypothesis to infer the financing regime underlying a negative (as well as a positive) investment response, and this test draws on the comparison of the effects of incentive pay and dividend taxes on investments.

Finally, corporate agency models can be distinguished by the manager's preference for investment. Compared to shareholders, managers prefer higher investments in empire-building models such as free cash flow models (Jensen, 1986). In contrast, in quiet life-type agency models, managers prefer lower investment levels as handling investments requires effort, which is costly to managers (Bertrand and Mullainathan, 2003). The model of this paper falls into the second category of corporate agency models, but offers a more nuanced perspective on the link between effort and investment. Quiet-life agency models generally resort to a reduced form representation of the positive relation between effort and investment. In our model, effort is costly to managers, but might decrease or increase with investment depending on how the two inputs interact in production. This ambiguity has implications for the efficiency effects of dividend taxation. Higher investments do not necessarily coincide with more managerial effort provision, thus potentially leading to efficiency losses.

In particular, Gordon and Dietz (2009) review the role of dividend taxes in classical, signaling, and agency models of firm behavior. Compared to other approaches, they find that agency models provide a sound explanation of empirical findings. 
The paper proceeds as follows. In Section 2 we set up an effort-based corporate agency model with endogenous incentive pay. In Section 3 we characterize the shareholders' choice of incentive pay, the managerial effort, and investment behavior and the welfare implications of dividend taxation. In Section 4 we turn to various extensions of the basic model and in Section 5 we relate the findings of the previous sections to empirical analyses of the effects of dividend taxation. Finally, we provide a summary of the results and offer some concluding remarks in Section 6 .

\section{Model}

Consider a managerial firm that exists for two periods. In period 1, the firm has initial cash holdings $X$ and might issue new shares at an amount $V_{1}^{N}$. Cash holdings and new share issues are used to finance investments $I$ and are residually distributed to shareholders as dividends, $D_{1}=X-I+V_{1}^{N} \geq 0$. In period 2 , the firm produces output. The production function is stochastic $F(I, e)=f(I, e)+\varepsilon$ with $\varepsilon \sim \mathcal{N}\left(0, \sigma^{2}\right) .{ }^{11}$ Production depends on investment $I$ and on managerial effort choices $e$, and satisfies $f_{I}, f_{e}>0, f_{I I}, f_{e e}<0$ and $f_{I e} \gtreqless 0{ }^{12}$

The cross derivative might capture different ways in which managerial effort interacts with physical investments. The two input factors might be substitutes, reflecting a situation in which managerial effort augments capital, thereby increasing the quality of the investment input, but not of other production factors. ${ }^{13,14}$ Such a situation might be captured by the production function $f(I, e)=\tilde{f}(h(e, I))$ with $\tilde{f}^{\prime}>0>\tilde{f}^{\prime \prime}$ and $h_{i}>0>h_{i i}, i=e, I$. The function $h(I, e)$ measures the quality of the capital input, which is enhanced by managerial effort provision and physical investment. Provided $h_{I e}$ is not too positive, the two inputs are substitutes, i.e., $f_{I e}<0 .{ }^{15}$ For instance, when $h(e, I)$ is additive, the production function is $f(I+e)$, which implies $f_{I e}<0$. The capital-augmenting view of managerial effort might apply when stricter managerial supervision (and thus higher effort) of the selection and implementation of

\footnotetext{
${ }^{11}$ To save on notation, we implicitly assume that the distribution of $\varepsilon$ is such that realized profits are nonnegative.

${ }^{12}$ Throughout the paper, subscripts denote partial derivatives where the order in which derivatives are taken is indicated by the sequence of subscripted variables.

${ }^{13}$ Other inputs might include fixed factors which, for simplicity, are omitted from the notation.

${ }^{14}$ For instance, see Tirole (2006) for moral hazard models that are consistent with the notion of substitutability.

${ }^{15}$ More precisely, the cross derivative is $f_{I e}=\tilde{f}^{\prime \prime} h_{e} h_{I}+\tilde{f}^{\prime} h_{I e}$. Given the assumptions stated above, the sign of $f_{I e}$ is negative when $h_{I e}$ is not too positive. Effort and investments might thus be complements in forming the quality of the capital input $h(I, e)$ and substitutes in overall production.
} 
investment projects increases the quality of the firm's investment choices. ${ }^{16}$ Alternatively, the productivity-enhancing effect of effort might not only be directed toward investments but might apply to all production factors, as described by the production function $f(I, e)=A(e) g(I)$, with $g^{\prime}>0>g^{\prime \prime}$ and $A^{\prime}>0 .{ }^{17}$ The productive effect of managerial effort goes through the efficiency parameter $A(e)$ of the production function. This implies $f_{I e}>0$. For example, the 'neutral' view of managerial effort might describe a situation in which the implementation of organizational changes or new management practices requires managerial effort and directly allows all production factors of the firm to be more productive.

Investments depreciate at a rate $\delta>0$. Profits are taxed at the rate $\tau>0$, where economic depreciation $\delta I$ and the fixed wage of the manager $a$ are deductible from the corporate tax base. At the end of period 2, the firm is liquidated and net of tax profits, and the liquidation proceeds $(1-\delta) I$ are distributed to shareholders. ${ }^{18}$ Thus, the flow of second-period dividends is given by:

$$
D_{2}=(1-\tau)(F(I, e)-a)+\tau \delta I+(1-\delta) I .
$$

Dividend distributions are taxed at rate $\tau^{D}$ at the shareholder level. Arbitrage behavior implies that firm value equals the stream of discounted net-of-tax dividend income corrected for new share issues. Hence:

$$
V=\left(1-\tau^{D}\right)\left(D_{1}+\frac{D_{2}}{1+r}\right)-V_{1}^{N}
$$

Shareholders offer the manager a share $\alpha$ of the firm and a fixed wage $a .{ }^{19}$ The manager is risk-averse and derives utility from income $w=\alpha V+\frac{a}{1+r}$ net of the costs of effort provision

\footnotetext{
${ }^{16} \mathrm{~A}$ microfoundation for $h(e, I)$ might be as follows. Assume a manager has a portfolio of projects under his/her control and influences the success of each project through his/her effort. There are two quality levels $I^{h}>I^{l}>0$. The two quality levels are increasing in physical investments $I$, i.e. $I_{I}^{i}>0, i=h, l$. By exerting effort, the manager makes some of the projects more successful, as measured by the differential $I^{h}-I^{l}$. The manager thereby decides on the relative importance of the two quality levels in the total capital stock where the aggregate quality level is $h(I, e)=e I^{H}+(1-e) I^{l}$. The ways in which effort and investments interact in production follow from $f_{I e}=\tilde{f}^{\prime \prime}\left(I^{h}-I^{l}\right)\left(e I_{I}^{h}+(1-e) I_{I}^{l}\right)+\tilde{f}^{\prime}\left(I_{I}^{h}-I_{I}^{l}\right)$. For instance, when physical investments symmetrically change, the two quality levels, $I_{I}^{h}=I_{I}^{l}$, effort and investments, turn out to be substitutes in production, $f_{I e}<0$.

${ }^{17}$ It should be noted that the production function $g(I)$ also captures the use of a fixed factor, which gives rise to diminishing returns $g^{\prime \prime}<0$.

${ }^{18}$ For simplicity, the corporate tax base does not include liquidation proceeds $(1-\delta) I$. The findings are unaffected by this modelling choice.

${ }^{19}$ Alternatively, shareholders might condition the equity compensation on before-tax dividend payments, assuming that, by construction, shareholders reimburse the dividend tax payments to managers. This is equivalent to making the firm liable for the dividend taxes that are due to the dividend payment the manager receives. The incidence and behavioral responses under the two means of levying the dividend tax are the same. In what follows, we assume that the incentive contract does not mechanically insulate managers from dividend taxes. The modelling choice might be congruent with the practice of incentive contracts, where managers pay dividend taxes and shareholders possibly adjust the after-tax sharing rate $\alpha$ to compensate managers for the dividend tax burden.
} 
$\phi(e)$, i.e. $E(U)=E(u(w))-\frac{\phi(e)}{1+r}$ with $u^{\prime}>0>u^{\prime \prime}$ and $\phi^{\prime}, \phi^{\prime \prime}>0$. Assuming utility over income to be CARA, we can simplify manager utility as $E(u(w))=E(w)-\rho \operatorname{Var}(w), \quad \rho>0$. Using (1), (2) and $w=\alpha V+\frac{a}{1+r}$, the mean and the variance of wage income are thus:

$$
E(w)=\alpha E(V)+\frac{a}{1+r} \quad \text { and } \quad \operatorname{Var}(w)=\rho\left(\alpha \frac{\left(1-\tau^{D}\right)(1-\tau)}{1+r}\right)^{2} \sigma^{2} .
$$

Therefore, manager utility is given by:

$$
E(U)=\alpha E(V)+\frac{a}{1+r}-\rho\left(\alpha \frac{\left(1-\tau^{D}\right)(1-\tau)}{1+r}\right)^{2} \sigma^{2}-\frac{\phi(e)}{1+r} .
$$

Shareholders must obey the participation constraint of the manager $E(U) \geq 0$ where the manager's reservation utility is normalized at zero. As manager remuneration is costly to shareholders, they will choose a wage schedule such that the participation constraint holds as an equality. Inserting $E(U)=0$ into external shareholder wealth $(1-\alpha) E(V)$, while noting (4) and $w=\alpha V+\frac{a}{1+r}$, yields the following:

$$
(1-\alpha) E(V)=E(V)+\frac{a}{1+r}-\rho\left(\alpha \frac{\left(1-\tau^{D}\right)(1-\tau)}{1+r}\right)^{2} \sigma^{2}-\frac{\phi(e)}{1+r} .
$$

Eq (5) shows that manager utility effectively enters shareholder wealth. Intuitively, given the participation constraint $E(U)=0$, shareholders become residual claimants, which induces them to account for manager utility.

The fiscal resources of the public sector, $T$, comprise dividend and corporate tax revenues:

$$
T=\tau^{D}\left(D_{1}+\frac{D_{2}}{1+r}\right)+\tau \frac{f(I, e)-a-\delta I}{1+r} .
$$

In the model, shareholders and the manager move sequentially. At the beginning of period 1 , shareholders decide on the incentive contract $(\alpha, a)$ and choose the level of equity injections $V_{1}^{N}$, anticipating the manager's choice of effort $e$ and investment $I$ at the end of period 1 . In period 2, production takes place, taxes are paid and the firm is liquidated.

\section{Retained Earnings as the Marginal Source of Funds}

We start out by assuming that investments are financed by retained earnings. In practice, retained earnings are the dominant source of investment finance and particularly so for mature firms (Auerbach and Hasset, 2002). In this setting, shareholders optimally set the level of new share issues to zero, $V_{1}^{N}=0$ (Sinn, 1987). The amount of retained earnings $X$ is used to finance investments $I$ and first-period dividend payments are determined as the residual after the firm finances all profitable projects from internal cash flow, $D_{1}=X-I \geq 0$. 


\subsection{Firm Behavior}

Solving backwards, the manager decides on investments and effort for given values of $\alpha$ and $a$. Inserting (2) into (4) while noting (1), $w=\alpha V+\frac{a}{1+r}$ and $D_{1}=X-I \geq 0$, the manager's choice of investment satisfies the following:

$$
I: \quad \alpha\left(1-\tau^{D}\right)\left(-1+\frac{(1-\tau) f_{I}+\tau \delta+1-\delta}{1+r}\right)=0 .
$$

The increase in second period dividend distributions due to higher investment equals the costs of reduced distributions in the first period. The manager symmetrically participates in the benefits and costs of investments. The incentive contract hence aligns the interests of the manager and of shareholders with respect to investment levels. The managerial effort choice follows from:

$$
e: \quad \alpha\left(1-\tau^{D}\right) \frac{(1-\tau) f_{e}}{1+r}-\frac{\phi^{\prime}(e)}{1+r}=0 .
$$

The marginal increase in net-of-tax profits assigned to the manager through the incentive contract is equated to the marginal costs of effort. As the manager privately bears the effort cost, but receives only a fraction of the total return on effort, the effort level is below the level shareholders prefer. ${ }^{20}$

From (7) and (8), we obtain:

$$
\frac{d e}{d \alpha}=-\frac{1}{|\Delta|} \frac{\alpha\left(\left(1-\tau^{D}\right)(1-\tau)\right)^{2}}{1+r} f_{e} f_{I I}>0 \quad \text { and } \quad \frac{d I}{d \alpha}=\frac{1}{|\Delta|} \frac{\alpha\left(\left(1-\tau^{D}\right)(1-\tau)\right)^{2}}{(1+r)^{2}} f_{e} f_{I e}
$$

where $|\Delta|>0$ is the determinant of the Hessian matrix of the manager's decision problem. From (9), a higher sharing parameter, $\alpha$, strengthens managerial incentives to exert effort. More effort provision changes the marginal productivity of investment, as captured by $f_{I e} \gtreqless 0$, and the interaction induced between effort and investment determines the sign of the investment response, i.e. $\operatorname{sign}\{d I / d \alpha\}=\operatorname{sign}\left\{f_{\text {Ie }}\right\}$. For instance, if effort and investments are complements in production, $f_{I e}>0$, higher effort provision strengthens incentives to invest.

In stage 1 , shareholders choose the incentive contract so as to maximize shareholder wealth (5), noting (1), (2), $w=\alpha V+\frac{a}{1+r}$ and $D_{1}=X-I$. Applying the envelope theorem, the associated first-order condition is:

$$
(1-\alpha) \frac{\left(1-\tau^{D}\right)(1-\tau) f_{e}}{1+r} \frac{d e}{d \alpha}=2 \alpha \rho\left(\frac{\left(1-\tau^{D}\right)(1-\tau)}{1+r}\right)^{2} \sigma^{2}
$$

\footnotetext{
${ }^{20}$ Shareholders prefer a level of effort that satisfies (8) with $\alpha=1$. The intuition is that shareholders are residual claimants, which entails that they are interested in aligning the total marginal increase in net-of-tax profit to the marginal cost of effort.
} 
The choice of $\alpha$ follows from an incentive-insurance trade-off (Holmstrom, 1979). As captured by the left-hand side of (10), a higher sharing parameter induces more effort provision which increases shareholder wealth. At the same time, a higher sharing parameter exposes the riskaverse manager to more risk, which shareholders need to compensate through a higher flat wage payment, $a$, so as to satisfy the manager's participation constraint $E(U)=0$. The associated marginal costs are captured on the right-hand side of (10).

Differentiating (10) with respect to $\alpha$ and $\tau^{D}$, and using (10) to rearrange terms, yields:

$$
\frac{d \alpha}{d \tau^{D}}=\left\{\frac{(1-\alpha)\left(1-\tau^{D}\right)(1-\tau)}{1+r} \frac{\partial\left(f_{e} \frac{d e}{d \alpha}\right)}{\partial \tau^{D}}+2 \alpha \rho \frac{\left(1-\tau^{D}\right)(1-\tau)^{2}}{(1+r)^{2}} \sigma^{2}\right\} \delta^{-1} .
$$

Given the second-order condition for $\alpha, \delta>0$ holds. Changes in tax policy have different effects on the shareholders' optimal choice of $\alpha$. A higher tax rate influences the incentive effect of a higher $\alpha$ on effort provision, c.f. the first term in curly brackets in (11). ${ }^{21}$ The impact on the sharing rate depends on how the incentive effect of equity-based compensation, as measured in output units $f_{e} d e / d \alpha$, varies with the tax rate, which is ambiguous in sign. ${ }^{22}$

Furthermore, as captured by the second term in curly brackets in (11), a higher tax exposes the manager to less income risk, which induces shareholders to expose the manager to more risk through a higher sharing rate.

Differentiating investment and effort with respect to $\tau^{D}$ yields:

$$
\frac{d e}{d \tau^{D}}=\frac{\partial e}{\partial \tau^{D}}+\frac{\partial e}{\partial \alpha} \frac{d \alpha}{d \tau^{D}} \quad \text { and } \quad \frac{d I}{d \tau^{D}}=\frac{\partial I}{\partial \tau^{D}}+\frac{\partial I}{\partial \alpha} \frac{d \alpha}{d \tau^{D}} .
$$

The first term in the two expressions captures the direct effect of the dividend tax on managerial choices, while the second term summarizes the indirect effect due to changes in the sharing parameter. The direct and indirect effect might be opposite in sign. Nonetheless, we can straightforwardly sign the overall responses by resorting to an equivalent representation of the managerial incentive contract and the behavioral responses that are induced by it. Rewriting the incentive contract by replacing $\alpha$ with $\tilde{\alpha}\left(1-\tau^{D}\right)^{-1}$ makes managerial pay independent of

\footnotetext{
${ }^{21}$ The effort-related reason to adjust the sharing parameter will vanish when incentives for effort provision are invariant to the tax rate $\tau^{D}$, i.e., $\partial e / \partial \tau^{D}=0$. To see this, note that:$$
\frac{\partial\left(f_{e} \frac{d e}{d \alpha}\right)}{\partial \tau^{D}}=\left(f_{e e} \frac{\partial e}{\partial \tau^{D}}+f_{e I} \frac{\partial I}{\partial \tau^{D}}\right) \frac{d e}{d \alpha}+f_{e} \frac{\partial}{\partial \tau^{D}} \frac{d e}{d \alpha} .
$$

From (7) and Young's Theorem, $\partial I / \partial \tau^{D}=0$ and $\partial(d e / d \alpha) / \partial \tau^{D}=0$ if $\partial e / \partial \tau^{D}=0$.

${ }^{22}$ Among other things, the sign of the expression $\partial\left(f_{e} d e / d \alpha\right) / \partial \tau^{D}$ depends on $\phi^{\prime \prime \prime}(e)$ (as part of the last term of the expression in footnote 21 ).
} 
the dividend tax and mechanically shifts the tax burden onto shareholders. The incidence and efficiency effects of corporate behavior are unaffected by the reformulation as shareholders are able to shift the tax burden back onto the manager by adjusting the sharing rate $\tilde{\alpha}^{23}$ As shown in Appendix A.1, using the re-formulated sharing rate $\tilde{\alpha}=\alpha\left(1-\tau^{D}\right)$, and re-iterating all steps to derive the optimal managerial choices and the sharing rate $\tilde{\alpha}$ yields $d e / d \tau^{D}<0$ and $\operatorname{sign}\left\{d I / d \tau^{D}\right\}=-\operatorname{sign}\left\{f_{I e}\right\}$. A higher dividend tax discourages effort provision and thereby influences investment levels depending on how the marginal productivity of investment varies with effort.

Multiple implications of the analysis are worth discussing at this point. The above finding is different to the standard notion of how dividend taxes affect investments when retained earnings are the marginal source of investment funds. As predicted by the new view of dividend taxation, a higher dividend tax leaves investments and thereby distributions to shareholders unchanged (c.f. Auerbach and Hasset, 2002). In the present setting, a higher dividend tax influences managerial effort choices and the investment behavior of firms. It raises investments and lowers distributions when effort and investments are substitutes in production, $f_{I e}<0$. The response is consistent with recent empirical findings. Becker et al. (2013) find a positive investment response to higher dividend taxes. Chetty and Saez (2005) show that corporate distributions increased in response to the U.S. dividend tax cut in 2003. This finding has been observed for mature firms in which retained earnings are frequently argued to be a major source of investment finance. ${ }^{24}$

Furthermore, the predictions of the model are observationally equivalent to the old view of dividend taxation when effort and investments are complements in production, $f_{I e}>0$. In this case, a higher dividend tax lowers investments. This observation is consistent with the managerial model presented here, in which retained earnings are the marginal source of funds, and with a neoclassical model of firm behavior in which new share issues are used to finance investments at the margin. While empirical papers often resort to dividend tax-induced investment changes to infer the marginal financing regime of a firm, the managerial model in this

\footnotetext{
${ }^{23}$ Intuitively, the equivalence result is related to the equivalence of levying taxes on the demand side or supply side of a market. The dividend tax, which relates to the dividend income of the manager, can be levied on the manager or on shareholders. Adjustments in the sharing rate will neutralize the way in which the manager's dividend tax is levied, but will not affect 'quantities', i.e., investment and effort choices.

${ }^{24}$ Corporate agency models of free cash flow equally predict that investment rises with dividend taxes when retained earnings are the marginal source of investment funds. See Kanniainen (1999) and Chetty and Saez (2010). Thereby, this paper corroborates the finding that positive investment responses to dividend taxes are consistent with optimal corporate behavior, once frictions within the firm are accounted for.
} 
case suggests that there is no clear relation between negative investment responses to dividend taxation and the underlying financing regime. In Section 4 we derive a testable hypothesis to distinguish between the two modes of finance in agency models based on observed investment changes.

A straightforward question is whether it is possible to narrow down $\operatorname{sign}\left\{f_{I e}\right\}$. Invoking production theory, the two cases $f_{I e} \gtrless 0$ may equally arise, as shown in Section 2. Also, comparing the differential predictions of the model with empirical evidence does not unequivocally restrict $\operatorname{sign}\left\{f_{I e}\right\}$. Precisely, from (9), the model predicts $\operatorname{sign}\{d I / d \alpha\}=\operatorname{sign}\left\{f_{I e}\right\}$ and, following (12), it implies $\operatorname{sign}\left\{d I / d \tau^{D}\right\}=-\operatorname{sign}\left\{f_{I e}\right\}$. For instance, Aggarwal and Samwick (2006) find $d I / d \alpha>0$ and the findings in Becker et al. (2013) include the response $d I / d \tau^{D}>0$, leading to dividend responses to taxes that are consistent with the results in Chetty and Saez (2005).

\subsection{Welfare}

The welfare measure includes shareholder wealth (5), which accounts for manager utility through the participation constraint of the manager, and expected tax revenues:

$$
W=E(V)+\frac{a}{1+r}-\rho\left(\alpha \frac{\left(1-\tau^{D}\right)(1-\tau)}{1+r}\right)^{2} \sigma^{2}-\frac{\phi(e)}{1+r}+E(T) .
$$

Tax revenues comprise dividend and corporate tax revenues, as given by (6). Differentiating welfare (13) with respect to $\tau^{D}$, while invoking the envelope theorem, yields:

$$
(1+r) \frac{d W}{d \tau^{D}}=\tau^{D}(1-\tau) f_{e} \frac{d e}{d \tau^{D}}+\tau\left(f_{e} \frac{d e}{d \tau^{D}}+\left(f_{I}-\delta\right) \frac{d I}{d \tau^{D}}\right)
$$

To disentangle the welfare effects of dividend taxation, it is instructive first to assume that effort is exogenous. In the absence of effort changes, investment levels are unaffected by dividend taxation, c.f. (7), (9), and (12). ${ }^{25}$ This result is consistent with the new view of dividend taxation, implying that dividend taxation exerts no efficiency effects. Dividend taxes fully capitalize in firm value and are neutral for welfare, $d W / d \tau^{D}=0$.

In the presence of non-verifiable effort choices, the dividend tax influences managerial effort provision and thereby investment levels. The associated change in shareholder wealth does not constitute an efficiency cost, which follows from the application of the envelope theorem. The incentive contract aligns incentives between shareholders and the manager such that investment

\footnotetext{
${ }^{25}$ More precisely, when $d e \equiv 0,(7)$ implies $\partial I / \partial \alpha=0$ and $\partial I / \partial \tau^{D}=0$. From (12), it then follows that $d I / d \tau^{D}=0$.
} 
levels are set so as to maximize shareholder wealth, c.f. (7). Hence, any tax-induced change in investments does not generate a first-order welfare loss. Possibly surprisingly, although effort choices do not maximize shareholder wealth (c.f. (8)), their first-order effect on shareholder wealth equally nullifies. Shareholders choose the sharing parameter $\alpha$ and thereby the exposure of the manager to dividend taxes $\alpha\left(1-\tau^{D}\right)$ optimally. As all effects of dividend taxes on effort work through the term $\alpha\left(1-\tau^{D}\right)$, shareholder wealth does not vary with effort (Chetty and Saez, 2010). ${ }^{26}$ Hence, shareholder wealth is insulated from behavioral responses that follow from dividend taxation, although the tax aggravates the pre-existing investment and effort distortion.

Still, managerial effort changes introduce two sources of welfare variation. Effort drops in response to a higher tax rate and lowers dividend tax revenues (c.f. the first term in (14)). The dividend tax revenue term captures a negative fiscal externality that shareholders and the manager exert on the public budget through the choice of the incentive contract and the managerial choice of effort and investment. This effect in isolation indicates that dividend taxation incurs an efficiency cost when retained earnings are the marginal source of funds. It should be noted that as the investment policy maximizes firm value, the effect of investment changes on dividend tax revenues vanishes due to an application of the envelope theorem.

The dividend tax change 'spills over' to corporate tax revenues. Less effort lowers taxable corporate profits, as depicted by the first term in brackets in (14). Furthermore, depending on $\operatorname{sign}\left\{f_{I e}\right\}$, effort adjustments change investment incentives, which affects corporate tax revenue, as summarized by the second term in brackets in (14). For instance, when investments and effort are complements in production, $f_{I e}>0$, a higher dividend tax reduces investments, which adds to the efficiency costs of dividend taxation through its negative effect on corporate tax revenues. A reversed type of reasoning applies when $f_{I e}<0$. In this case, higher dividend taxes spur investments generating a positive effect on corporate tax revenues. As the investment response follows from effort changes and thereby is of second order compared to the effort response, the positive investment-related fiscal externality will most likely not compensate for the negative fiscal externality on corporate tax revenues following from managerial effort provision.

\footnotetext{
${ }^{26}$ Differentiating (5) with respect to $\tau^{D}$, while accounting for $(7)$ and (8), and noting $\frac{d e}{d \tau^{D}}=\left(1-\tau^{D}\right) \frac{d e}{d \alpha\left(1-\tau^{D}\right)}$, the change in shareholder wealth (net of the mechanical tax effect which is neutral for efficiency) is given by:

$$
\frac{1}{1-\tau^{D}}\left((1-\alpha) \frac{\left(1-\tau^{D}\right)(1-\tau) f_{e}}{1+r} \frac{d e}{d \alpha}-2 \alpha \rho\left(\frac{\left(1-\tau^{D}\right)(1-\tau)}{1+r}\right)^{2} \sigma^{2}\right) \frac{d \alpha\left(1-\tau^{D}\right)}{d \tau^{D}} .
$$

Given the first-order condition for the choice of $\alpha$ in (10), the partial effect of dividend taxation vanishes.
} 
The welfare term (14) can be related to the discussion of income-shifting incentives and the associated welfare implications (Slemrod, 1995; Gordon and Slemrod, 2000). ${ }^{27}$ Changes in the dividend tax affect incentives to remunerate the manager either through dividend payments or a wage payment $a$, and thereby to save on taxes levied on each of the two forms of remuneration. ${ }^{28}$ Thus, income shifting might come at an efficiency cost. Precisely, the residually determined adjustment in $a$ (so as to satisfy the manager's participation constraint) is neutral for efficiency as it carries no behavioral responses. However, as captured by (14), the change in $\alpha$ induces efficiency effects and the efficiency effects follow from effort as well as investment changes. The observation is different from the standard notion of how income shifting affects welfare. The latter is related to the mechanical shifting of income between different tax bases, most notably the dividend tax base and the wage tax base. ${ }^{29}$

\section{Extensions}

\subsection{The ACE Tax System and Cash-Flow Taxation}

Corporate taxation generally discourages investments. This follows from the asymmetric tax treatment of the investment cost and the return on investment. The corporate tax fully taxes the return whilst generally offering only an imperfect tax deductibility for the cost of investment. The issue of whether this cost should be fully tax deductible is central to tax reform discussions in many countries (for instance, see Auerbach et al., 2010). Two frequently discussed tax systems that offer a symmetric tax treatment are the R-based cash flow tax and the allowance for corporate equity (ACE) system. The two tax systems differ with respect to the timing of the reimbursement of the full cost of investment. The R-based cash flow tax offers an immediate write-off of the investment, coupled with the taxation of liquidation proceeds. The ACE system offers a tax deductibility of the cost of investment finance, combined with a depreciation allowance, after the investment has been made (Boadway and Bruce, 1984; Devereux and Freeman, 1991). The two tax systems are equivalent in the current setting. As a matter of choice, we consider an R-based cash flow system in what follows. The latter system alters aggregate

\footnotetext{
${ }^{27}$ See Saez et al. (2012) for a survey of the literature.

${ }^{28}$ We may extend the analysis to include a wage $\operatorname{tax} \tau^{W}$ on the fixed salary payment $a$ to formally introduce different tax bases related to managerial pay.

${ }^{29} \mathrm{We}$ are able to replicate the standard mechanical income-shifting effect and its relevance for welfare by assuming that tax revenues are not rebated in a lump-sum fashion, but through distortionary taxes. This implies multiplying tax revenues $T$ in (13) by $\lambda>1$, where $\lambda$ captures the marginal cost of public funds with distortionary taxes.
} 
tax revenues to:

$$
T=\tau^{D}\left(D_{1}+\frac{D_{2}}{1+r}\right)+\tau\left(-I+\frac{f(I, e)-a}{1+r}+\frac{(1-\delta) I}{1+r}\right) .
$$

The first and third terms in the second brackets are new. They represent the tax deductibility of the costs of investment and the inclusion of the proceeds of liquidation in the corporate tax base. Noting that first-period dividends now become $D_{1}=X-(1-\tau) I \geq 0$, the manager's choice of investment satisfies the following:

$$
I: \quad \alpha\left(1-\tau^{D}\right)(1-\tau)\left(-1+\frac{f_{I}+1-\delta}{1+r}\right)=0 \quad \Leftrightarrow \quad f_{I}=r+\delta,
$$

while managerial effort choices still follow from (8). The tax system treats the investment cost and benefits symmetrically, leaving the investment choice undistorted. Conditional on effort choices, investment levels are insulated from corporate taxation as well as dividend taxation. However, from (8) and (16), dividend taxation undermines managerial effort provision, and depending on $\operatorname{sign}\left\{f_{I e}\right\}$, this 'spills over' to the investment choice, as before. As such, effort levels are negatively related to dividend taxes and the associated tax-induced investment response depends on $\operatorname{sign}\left\{f_{I e}\right\}$.

Using (13) and (15) and applying the envelope theorem, we find:

$$
\left.(1+r) \frac{d W}{d \tau^{D}}=\tau^{D}(1-\tau) f_{e} \frac{d e}{d \tau^{D}}+\tau(\overbrace{f_{I}-r-\delta}^{=0}) \frac{d I}{d \tau^{D}}+f_{e} \frac{d e}{d \tau^{D}}\right) .
$$

From (16) we obtain $f_{I}=r+\delta$, which implies that the effect of investments on corporate tax revenues vanishes. This finding might be surprising, given that investments change with dividend taxation. However, the manager symmetrically participates in all benefits and costs of investments through the incentive contract, which at the margin insulates tax revenues and thereby welfare from investment changes. ${ }^{30}$ The dividend tax influences effort and this behavioral response is sufficient to calculate the efficiency costs of dividend taxation. We should note that the welfare neutrality of investment responses is different from the new view of dividend taxation in which dividend taxation does not influence investment levels.

\subsection{New Share Issues}

Firms might not have sufficient internal funds to finance investments, and therefore might resort to new share issues as the marginal source of funds. This might particularly apply to newly

\footnotetext{
${ }^{30}$ As before, private welfare is insulated from tax-induced investment changes, which is an implication of the envelope theorem.
} 
created, immature firms that are still in the growth phase. Such firms have not accumulated a sufficient amount of retained earnings to finance investments and thus rely predominantly on external equity finance. This mode of financing marginal investments underlies the old view of dividend taxation (Poterba and Summers, 1985).

With new share issues in the first period, we have $V_{1}^{N}>0$ and $D_{1}=0$. Noting that the firstperiod resource constraint becomes $D_{1}=X-I+V_{1}^{N}=0$, the manager's choice of investment satisfies the following:

$$
I: \quad \alpha\left(-1+\frac{\left(1-\tau^{D}\right)\left((1-\tau) f_{I}+\tau \delta+1-\delta\right)}{1+r}\right)=0 .
$$

The first-order condition (17) differs from (7). Intuitively, the government shares in the return to investment, but provides no subsidy to the costs of equity investments. Thereby, the dividend tax undermines investment incentives, conditional on effort. The distortion arising from the asymmetric tax treatment mirrors the old view of dividend taxation (Poterba and Summers, 1985). Different to investment choices, the first-order condition for managerial effort choices continues to be given by (8).

Two implications are noteworthy at this point. First, in the case of external equity finance, dividend taxes influence investment behavior not only indirectly through effort changes, but also directly. Compared to the situation with retained earnings as the marginal source of funds, the direct effect downwardly influences the investment response $d I / d \tau^{D}$. As such, even when investments and effort are substitutes in production $\left(f_{I e}<0\right)$, the investment response to dividend taxation might be negative in sign. Second, and related to the previous observation, the tax-induced investment response can take any sign. This finding argues against the ability to infer the firm's financing regime from observed investment behavior as is feasible in the case of the neoclassical model of firm behavior. Recall, in the latter model, a negative investment change in response to dividend taxation is consistent with the use of new share issues as the marginal source of funds. In contrast, investments do not vary with dividend taxes when retained earnings finance investments at the margin. The agency model nevertheless offers some guidance on the ability to infer the mode of financing based on the firm's investment response. Key to the identification is the finding that equity-based incentive pay $\alpha$ and the dividend tax factor $\left(1-\tau^{D}\right)$ exert the same impact on investments that are financed out of retained earnings, while $\alpha$ and $\left(1-\tau^{D}\right)$ differentially affect investments financed through new share issues. More precisely, from (7) and (8), the term $\alpha\left(1-\tau^{D}\right)$ summarizes the effect of the sharing parameter and the 
dividend tax on investment and effort choices when retained earnings are sufficient to finance investment outlays. Intuitively, the incentive contract and the dividend tax base depend on the same set of variables, which includes the equity costs of investment and the profit net of corporation tax. With new share issues, the equity costs of investment are excluded from the dividend tax base, but the incentive contract still depends on these costs (c.f. (7) and (17)). It follows that investments respond more strongly to tax changes than to changes in the sharing parameter. Hence, using superscripts re and nsi for retained earnings and new share issues as the marginal source of finance, we find:

$$
\frac{\partial I^{r e}}{\partial \alpha}=\frac{\partial I^{r e}}{\partial\left(1-\tau^{D}\right)} \quad \text { and } \quad \frac{\partial I^{n s i}}{\partial \alpha}<\frac{\partial I^{n s i}}{\partial\left(1-\tau^{D}\right)} .
$$

We should note that the suggested identification in (18) relies on general features of the incentive contract and the definition of the dividend tax base. Thus, it does not only apply to an effort-based agency model, as used here, but also to free cash flow models (Jensen, 1986) (1 $^{31}$ and models of managerial overconfidence (Malmendier and Tate, 2005) ${ }^{32}$, two further prominent types of corporate agency models. In these models (as in the managerial effort model), the sharing parameter applies to all corporate distributions. In contrast, the dividend tax is based on all distributions when retained earnings are used at the margin, but excludes the costs of investment when new share issues are the marginal source of funds.

\subsection{Taxation of Equity-Based Incentive Wages}

Recent tax policy discussions center on the issue of whether equity-based managerial wages should be taxed differently to general wage income. The proposed rationale is that equitybased wages might well influence managerial behavior in socially undesirable ways and a tax on managerial wages might at least partially correct for this (see, for instance, Benabou and Tirole, 2015; Murphy, 1999, and Piketty et al, 2014)..$^{33}$

\footnotetext{
${ }^{31}$ For instance, see Kanniainen (1999), Chetty and Saez (2010) and Koethenbuerger and Stimmelmayr (2014) for an analysis of tax policy in this type of corporate agency model.

${ }^{32}$ In models of managerial overconfidence, the non-congruence of interests between shareholders and managers is related to the too optimistic beliefs managers have with respect to the desirability of investment projects.

${ }^{33}$ For instance, the agency model abstracts from the effort that the manager might exert to improve his or her bargaining power in the wage negotiation process, as in Piketty et al. (2014). To capture this, we could introduce a decision stage prior to the choice of the incentive contract, at which point the manager might take actions to improve the outside option $\bar{U}$ (normalized at zero in the model). As such, total wage income increases. The effort related to this activity is socially wasteful as it only influences the distribution of payoffs between the manager and shareholders. The extension will not change the basic finding of this section. A formal analysis is available upon request.
} 
In what follows, we assume that the equity-based incentive income of the manager is taxed at the personal income tax rate $\tau^{E}$. The net of tax income of the manager is $w=\left(1-\tau^{E}\right) \alpha V+\frac{a}{1+r}$. The expected utility of the manager is given by:

$$
E(U)=\left(1-\tau^{E}\right) \alpha E(V)+\frac{a}{1+r}-\rho\left(\alpha \frac{\left(1-\tau^{E}\right)\left(1-\tau^{D}\right)(1-\tau)}{1+r}\right)^{2} \sigma^{2}-\frac{\phi(e)}{1+r}, \quad \rho>0 .
$$

From (19), we can conclude that conditional on $\alpha$, the two taxes $\tau^{E}$ and $\tau^{D}$ are equivalent in terms of their impact on the manager's choice of investment and effort. At the beginning of the first period, shareholders choose the incentive contract, and the manager accepts the incentive contract and works for the firm provided the participation constraint $E(U)=0$ holds. Inserting $E(U)=0$ into external shareholder wealth $(1-\alpha) E(V)$, while noting (19), yields:

$$
(1-\alpha) E(V)=E(V)+\frac{1}{1-\tau^{E}}\left(\frac{a}{1+r}-\rho\left(\alpha \frac{\left(1-\tau^{E}\right)\left(1-\tau^{D}\right)(1-\tau)}{1+r}\right)^{2} \sigma^{2}-\frac{\phi(e)}{1+r}\right) .
$$

Maximizing (20) with respect to the sharing parameter $\alpha$, while applying the envelope theorem, the first-order condition is as follows:

$$
(1-\alpha) \frac{(1-\tilde{\tau}) f_{e}}{1+r} \frac{d e}{d \alpha}=2 \alpha \rho\left(\frac{1-\tilde{\tau}}{1+r}\right)^{2} \sigma^{2}
$$

where $1-\tilde{\tau}=\left(1-\tau^{D}\right)\left(1-\tau^{E}\right)(1-\tau)$. It becomes evident from the optimality condition that shareholders perceive the dividend $\operatorname{tax} \tau^{D}$ and personal income tax $\tau^{E}$ as equivalent tax instruments. This might be surprising as the personal income tax only applies to the manager. However, shareholders become residual claimants and residually receive all utility gains above the reservation utility. Effectively, the personal income tax becomes a tax on shareholder wealth and is equivalent to the dividend $\operatorname{tax} \tau^{D}$ in its effect on the sharing parameter in the incentive contract. Combining this insight with the previous conditional equivalence results, which relate to the tax effect on investments and effort for a given value of $\alpha$, the two tax instruments become equivalent in terms of their implications for manager and shareholder behavior, and thus also in terms of their effects on welfare. ${ }^{34}$ As a consequence, the model predicts that a special tax on the equity-based wage of the manager is redundant and the same efficiency effects can be achieved through the general dividend $\operatorname{tax} \tau^{D}$.

A natural question is the extent to which the equivalence result carries over to other forms of managerial wage determination, such as Nash bargaining. ${ }^{35}$ With Nash bargaining, the sharing

\footnotetext{
${ }^{34}$ Note the relevant welfare measure now comprises private welfare (20) plus tax revenues (6), which needs to be augmented by the tax payment $\tau^{E} \alpha V$.

${ }^{35}$ See Kleven et al. (2014) for a recent application of the widely used approach in the context of top-income earners.
} 
rate is determined by maximizing the product of the manager utility and shareholder utility (net of the value of the respective outside option). From (2), shareholder utility $(1-\alpha) E(V)$ is a fraction $\left(1-\tau^{D}\right)$ of the received stream of dividend payments. This term scales the product of the two utilities, but will not change the bargaining outcome. In contrast, the dividend tax and personal income tax influence manager utility through the tax term $\left(1-\tau^{D}\right)\left(1-\tau^{E}\right){ }^{36}$ Given the additive structure of manager utility $E\left(U^{M}\right)=E(u(w))-\frac{\phi(e)}{1+r}$, the tax term will not factor out of manager utility and will thereby influence the bargaining solution. The two tax instruments $\tau^{D}$ and $\tau^{E}$ are thus equivalent in determining the Nash bargaining outcome, and also in their direct effects on investment and effort (c.f. (19)). See Appendix A.2 for a more formal analysis of this issue.

\section{Discussion}

A considerable body of literature has evaluated the validity of the old view and new view of dividend taxation, using a variety of methods to determine the impact of dividend taxation on corporate investment and distributions. Depending on data availability and the methods applied, some analyses determine the marginal source of finance, and based on the diverging predictions of the two views, infer the efficiency effects of dividend taxation. Alternatively, studies have tested the implications of either dividend taxes for corporate payout and investment behavior, or of investment changes for distributions, and infer the marginal source of funds from these responses (see Auerbach, 2002, for an overview of the literature). ${ }^{37}$ The two methods are informative in different says in terms of the efficiency effects of dividend taxation in the agency model used in this case. Knowing the marginal source of funds is informative in itself, but it is not sufficient to draw conclusions concerning dividend tax neutrality. When investments are financed out of retained earnings, dividend taxation might also change investment incentives, yielding observable investment responses to taxes that are opposite to the predictions of the two

\footnotetext{
${ }^{36}$ This insight holds for different specifications of the outside option of shareholders, including the scenario that the manager is indispensable to the firm $\left(\bar{U}^{S}=0\right)$ and that shareholders will find a replacement for the manager when negotiations break down in terms of who then runs the firm, possibly at a reduced firm value.

${ }^{37}$ For instance, to infer the source of funds for investments, Auerbach and Hasset (2002) look at the sensitivity of dividend payments to investments. They make use of the testable prediction that under the new view, dividends are residually determined and decline as investment spending increases, whereas investments have no immediate impact on distributions under the old view. Poterba and Summers (1985) estimate investment equations based on Tobin's q-theory of investment, which includes the new and old views as special cases. Poterba (2004) analyzes corporate payout policies to disentangle the empirical relevance of the two views and Chetty and Saez (2005) investigate how dividend payments change with dividend taxes.
} 
views. For instance, investments might be unresponsive to dividend taxation with new share issues at the margin (provided $f_{I e}<0$ ), while they affect new investments that are financed by retained earnings. Conversely, empirical estimates of dividend tax effects on investments cannot be connected in a straightforward manner to a financing regime. Dividend taxes might well distort investment levels downward under either source of finance. However, as shown above, the agency model provides auxiliary predictions which make it possible to infer the financing regime based on empirically observed investment behavior. With retained earnings as the marginal source of funds, investment responses to dividend taxes and to the performancerelated sensitivity of managerial wages ( $\alpha$ in our model) are identical, while the two responses differ with new share issues as the marginal source of funds (c.f. (18)).

The agency model and the neoclassical model of firm behavior generate identical qualitative implications for the differential response of investments in a retained earnings (re) vs. new share issues $(n s i)$ regime. In both models, the difference $I^{r e}-I^{n s i}$ is increasing in the dividend tax. ${ }^{38}$ Some empirical analyses use such relative responses as the outcome variable. For instance, Becker et al. (2013) and Alstadsæter et al. (2015) divide the firm sample into firms that are likely to use new share issues or retained earnings to finance new investments (proxied by the access to equity markets or by cash holdings) and relate the tax-induced investment response of the two firm groups to each other. They find that the empirically observed relative investment changes are generally negative in sign, and thus consistent with the old and new views of dividend taxation. Against the background of this paper, their findings can be interpreted more broadly as there is also a carry over to the agency model of firm behavior. Unfortunately, the differential response tends not to be sufficient to calculate the efficiency costs of dividend taxation in the agency model. It generally requires knowledge of investment responses under each of the two financing regimes. The information can be inferred from the relative investment response in the neoclassical model of firm behavior, but less so in agency models as investments change under both modes of finance. ${ }^{39}$ In an environment in which firms are pre-clustered in groups according to their presumed marginal source of funds (as in Becker et al., 2013, for instance), the auxiliary prediction (18) suggested in this paper might be useful to verify the consistency of

\footnotetext{
${ }^{38}$ In the neoclassical model the differential investment response follows from the dividend tax neutrality under the new view of dividend taxation, that is, changes in the investment difference $I^{r e}-I^{n s i}$ are exclusively related to changes in $I^{n s i}$. In the agency model in this case, the difference in responses qualitatively follows from the direct negative effect the dividend tax has on investments when new share issues are used at the margin (c.f. (7) and (17))

${ }^{39}$ In the neoclassical model, $I^{r e}-I^{n s i}$ only changes because of the response in $I^{n s i}$, i.e., $d I^{n s i} / d \tau^{D}<0$.
} 
the pre-assignment of firms with the essence of a large class of corporate agency models.

Alstadsæter et al. (2015) found relative dividend payouts $D^{r e}-D^{n s i}$ increased after a dividend tax reduction in Sweden. This response is consistent with predictions of the model with perk investments in Chetty and Saez (2010) and of the current model with productive investments, provided $f_{I e}<0$. Key to the explanatory power of the two models is the prediction that dividend taxes increase investment outlays and thereby decrease instantaneous dividend payouts $D^{r e}$ of firms with a sufficient amount of retained earnings, while naturally leaving instantaneous payouts $D^{n s i}$ at a zero level. The efficiency implications of investment responses underlying a rise in dividend payouts in the two models differ however. More perks lower efficiency, while more productive investment enhances the efficiency of resource allocation, a differential prediction which goes against the welfare interpretation of the findings in Alstadsæeter et al. (2015).

Using the 2003 U.S. dividend tax cut as a policy experiment, Yagan (2015) finds no significant tax effect on investment of firms that are subject to dividend taxation. As discussed in this paper, such a finding might be related to firm-specific responses to the dividend tax cut, as analyzed in Chetty and Saez (2010). The diverging responses reflect inefficiencies due to corporate agency problems, which might offset each other in aggregate. In particular, firms might use different sources of finance, giving rise to counteracting investment responses to dividend taxes. ${ }^{40}$ This model provides a different mechanism that is consistent with the empirical finding. The heterogeneity of firm responses due to heterogeneity in the sign and the magnitude of $f_{I e}$ might generate investment responses that might well neutralize in aggregate. The heterogeneity in investment responses might be related not only to firms that resort to different sources of finance at the margin but also to firms that use the same source of investment finance, as in the model employed here. Interestingly, against the background of this model, dividend taxes incur efficiency costs due to adjustments in managerial effort levels even when investments do not vary with the dividend tax (due to firm-level heterogeneity in $f_{I e}$, for instance). This allows for the interpretation that the US dividend tax cut might have increased efficiency although aggregate corporate investment has not changed. ${ }^{41}$ It is interesting to note that such heterogeneity might also explain why the literature does not find a systematic relationship between investment and

\footnotetext{
${ }^{40}$ In the free cash flow model used in Chetty and Saez (2010) investment outlays rise with dividend taxation when retained earnings are sufficient to finance investments, but might drop with new share issues.

${ }^{41}$ Note, the response $d e / d \tau^{D}$ is independent of $\operatorname{sign}\left\{f_{I e}\right\}$. It influences the welfare cost of dividend taxation (14) also when firm-level heterogeneity in $\operatorname{sign}\left\{f_{I e}\right\}$ nullifies the aggregate investment response.
} 
tax rates (Desai and Goolsbee, 2004). Indeed, Desai and Goolsbee find that the U.S. dividend tax reductions enacted in 2003 had little or no effect on investment.

\section{Summary and Concluding Remarks}

Efficiency analysis of dividend taxes in public finance is not firmly connected to corporate agency theory. This paper analyzes the efficiency costs of dividend taxation in an effort-based corporate agency model in which non-verifiable managerial effort enhances taxable profits. We show that, in contrast to traditional efficiency analysis, the source of investment finance and the sensitivity of investment to dividend taxes are not uniquely linked. Investment might be distorted downward when retained earnings or new equity issue finance investments at the margin. We provide a testable implication to infer the mode of investment finance from the investment sensitivity to dividend taxes and incentive provision. The theory-guided empirical strategy might be particularly helpful in environments in which this piece of financial information is otherwise difficult to retrieve from the data. In addition, we demonstrate that efficiency effects generally depend on tax-induced investment and effort responses. However, in the case of an ACE system or an R-based cash flow tax system, dividend taxes do not impair efficiency due to investment changes, rendering observable investment responses uninformative for efficiency analysis. Finally, we show that imposing an income tax on managerial equity pay is equivalent to a general dividend tax. From this perspective, our paper suggests a cautious efficiency-based demand for such a type of managerial tax.

Different extensions to the analysis are conceivable. For instance, firms might be finance constrained, as frequently documented. With finance constraints, corporate investments fall short of the level that maximizes firm profits. An immediate implication is that investments are invariant to dividend taxes. ${ }^{42}$ However, this does not imply that dividend taxes are welfare neutral, as in the neoclassical model of firm behavior. They continue to lower managerial effort provision and incur efficiency costs. ${ }^{43}$ A further extension might address coordination

\footnotetext{
${ }^{42}$ With finance constraints $\left(D_{1}=X-I=0\right)$, the first-order condition $(7)$ is replaced by $(1-\tau) f_{I}+\tau \delta+1-\delta>$ $1+r$. Managerial effort choices are qualitatively unaffected by the existence of finance constraints and continue to follow from (8). Consequently, the fiscal externality of investments on the public budget becomes zero and all efficiency effects of dividend taxation are related to the negative managerial effort response $d e / d \tau^{D}($ c.f. $(14)$ ).

${ }^{43}$ Firms might also be heterogeneous in their exposure to finance constraints and the exposure is endogenous to the managerial effort choice (through its effect on $f_{I}$ ). Firm heterogeneity might be related to different managerial costs of effort provision $\phi(e)=\omega \tilde{\phi}(e)$, where $\omega$ differs across firms. In such a world, the investment response in the fiscal externality term (14) needs to be weighted by the mass of firms that are not finance constrained, thereby leaving the results qualitatively intact. A formal treatment of this extension is available upon request.
} 
problems between shareholders, which imply that not all, but only a subset of shareholders (e.g., majority shareholders) decide on the incentive contract. In such an environment, dividend taxes will exert additional efficiency costs as the coordination problem between shareholders leads to an externality that majority shareholders impose on minority shareholders. Despite being interesting, we leave a formal treatment of this and other possible extensions to future research.

\section{A Appendix}

\section{A.1 Gross definition of the incentive contract}

Assume that the managerial incentive contract is a tuple $(\tilde{\alpha}, a)$ where $\tilde{\alpha}$ is the fraction of beforetax dividend payments that accrue to the manager and $a$ is a fixed wage payment, i.e.:

$$
w=\tilde{\alpha}\left(D_{1}+\frac{D_{2}}{1+r}\right)+\frac{a}{1+r} .
$$

With the gross definition of the incentive contract, manager utility is given by:

$$
E(U)=\tilde{\alpha}\left(D_{1}+\frac{E\left(D_{2}\right)}{1+r}\right)+\frac{a}{1+r}-\rho\left(\tilde{\alpha} \frac{(1-\tau)}{1+r}\right)^{2} \sigma^{2}-\frac{\phi(e)}{1+r} .
$$

Solving backwards, at stage 2 the manager chooses the level of investment and effort. Using (1), $D_{1}=X-I \geq 0$, and (23), the manager's choice of investment and effort follow from:

$$
I: \quad \tilde{\alpha}\left(-1+\frac{(1-\tau) f_{I}+\tau \delta+1-\delta}{1+r}\right)=0
$$

and

$$
e: \quad \tilde{\alpha} \frac{(1-\tau) f_{e}}{1+r}-\frac{\phi^{\prime}(e)}{1+r}=0 .
$$

The first-order conditions implicitly define investment and effort as a function of $\tilde{\alpha}$, i.e. $I(\tilde{\alpha})$ and $e(\tilde{\alpha})$, where:

$$
\frac{d e}{d \tilde{\alpha}}>0 \quad \text { and } \quad \frac{d I}{d \tilde{\alpha}} \gtreqless 0 \quad \Leftrightarrow \quad f_{I e} \gtreqless 0 .
$$

Shareholder wealth is given by:

$$
\left(1-\tau^{D}\right)(1-\tilde{\alpha})\left(D_{1}+\frac{E\left(D_{2}\right)}{1+r}\right)-\tau^{D} \tilde{\alpha}\left(D_{1}+\frac{E\left(D_{2}\right)}{1+r}\right)=\left(1-\tilde{\alpha}-\tau^{D}\right)\left(D_{1}+\frac{E\left(D_{2}\right)}{1+r}\right)
$$

Using the manager's participation constraint $E(U)=0$ and (23), shareholder wealth becomes:

$$
\left(1-\tau^{D}\right)\left(D_{1}+\frac{E\left(D_{2}\right)}{1+r}\right)+\frac{a}{1+r}-\rho\left(\tilde{\alpha} \frac{(1-\tau)}{1+r}\right)^{2} \sigma^{2}-\frac{\phi(e)}{1+r}
$$


At stage 1, shareholders choose the incentive contract so as to maximize shareholder wealth (27), noting (1) and $D_{1}=X-I$. Applying the envelope theorem, the associated first-order condition is as follows:

$$
\left(1-\tau^{D}\right)(1-\tilde{\alpha}) \frac{(1-\tau) f_{e}}{1+r} \frac{d e}{d \tilde{\alpha}}=2 \tilde{\alpha} \rho\left(\frac{1-\tau}{1+r}\right)^{2} \sigma^{2} .
$$

Noting that investment and effort do not depend on $\tau^{D}$ (c.f. (24) and (25)), differentiation of (28) with respect to $\tilde{\alpha}$ and $\tau^{D}$ yields:

$$
\frac{d \tilde{\alpha}}{d \tau^{D}}=\left(\frac{-(1-\tilde{\alpha})(1-\tau)}{1+r} f_{e} \frac{d e}{d \tilde{\alpha}}\right) \delta^{-1}<0
$$

where, due to the second-order condition for the choice of $\tilde{\alpha}$, we have $\delta>0$.

The equivalence between the net definition of the incentive contract, as used in the paper, and the gross definition follows from the possibility to transform the first-order conditions for investment, effort, and the sharing parameter ((24), (25), and (28)) into the respective firstorder condition under the net definition of the incentive contract $((7),(8)$, and (10)). These can be transformed using the relation $\tilde{\alpha}=\left(1-\tau^{D}\right) \alpha$, and based on this, $d \iota / d \alpha=\left(1-\tau^{D}\right) d \iota / d \tilde{\alpha}$, $\iota=I, e$.

Hence, the responses of the behavioral margins to changes in the dividend tax must be the same under the two definitions. Differentiating investment and effort with respect to $\tau^{D}$ yields:

$$
\frac{d e}{d \tau^{D}}=\frac{d e}{d \tilde{\alpha}} \frac{d \tilde{\alpha}}{d \tau^{D}}<0 \quad \text { and } \quad \frac{d I}{d \tau^{D}}=\frac{d I}{d \tilde{\alpha}} \frac{d \tilde{\alpha}}{d \tau^{D}} \lesseqgtr 0 \quad \Leftrightarrow \quad f_{I e} \gtreqless 0 .
$$

The sign of the responses in (30), and thereby the sign of the responses in (12), follows from (26) and (29).

\section{A.2 Nash bargaining}

We slightly modify the notation by denoting $\bar{U}^{M}$ and $\bar{U}^{S}$ as the outside option of the manager and shareholders, respectively. With Nash bargaining, the maximand of the bargaining problem is given by:

$$
\left(E\left(U^{M}\right)-\bar{U}^{M}\right)^{\beta}\left(E\left(U^{S}\right)-\bar{U}^{S}\right)^{1-\beta},
$$

where $E\left(U^{M}\right)$ and $E\left(U^{S}\right)$ is the expected utility of the manager and of shareholders respectively. The exponent $\beta \in[0.1]$ represents the bargaining power of the manager (and $1-\beta$ is the bargaining power of shareholders). Note, for $\beta=0$ the specification reduces to the model analyzed in the main part of the paper. From (2), shareholder utility $E\left(U^{S}\right)=(1-\alpha) E(V)$ 
is proportional to the 'before-dividend-tax' shareholder utility, where the proportionality factor is $1-\tau^{D}$. Provided the shareholders' outside option entails a continuation of the firm and of the liability to dividend taxation, ${ }^{44}$ the tax factor $1-\tau^{D}$ scales the difference $E\left(U^{S}\right)-\bar{U}^{S}$ and thereby the maximand of the Nash bargaining problem (31). It will thereby not influence the choice of the incentive contract. Technically, the Nash bargaining solution is immune to the scaling of shareholder utility net of the outside option due to its axiomatic construction which involves invariance to equivalent utility representations (see Osborne and Rubinstein, 1990).

In contrast, manager utility depends on the tax factor $\left(1-\tau^{D}\right)\left(1-\tau^{E}\right)$ and is additive in structure, $E\left(U^{M}\right)=E(u(w))-\frac{\phi(e)}{1+r}$, where the last term is not mechanically related to $\left(1-\tau^{D}\right)\left(1-\tau^{E}\right)$. This implies that the tax term $\left(1-\tau^{D}\right)\left(1-\tau^{E}\right)$ does not factor out of $E\left(U^{M}\right)$. Finally, we conjecture that the two taxes $\tau^{D}$ and $\tau^{E}$ influence the manager's outside option through the tax factor $\left(1-\tau^{D}\right)\left(1-\tau^{E}\right)$, if at all. For instance, this naturally happens when the outside option also entails a managerial job with equity-based remuneration or a job for which the remuneration is not subject to the two taxes (only a fixed-wage payment, for instance). In this case, the effect of the two taxes on the bargaining outcome goes through the tax term $\left(1-\tau^{D}\right)\left(1-\tau^{E}\right)$. Hence, the tax on managerial incentive pay $\tau^{E}$ is equivalent to a general dividend $\operatorname{tax} \tau^{D}$, both in terms of induced firm responses and efficiency.

\section{References}

[1] Aggarwal, R. and A. Samwick (2006), Empire-builders and shirkers: Investment, firm performance, and managerial incentives, Journal of Corporate Finance, 12, 489-515.

[2] Alstadsæter, A., M. Jacob, and R. Michaely (2015), Do dividend taxes affect corporate investment?, Journal of Public Economics, forthcoming.

[3] Auerbach, A.J. (1979), Wealth maximization and the cost of capital, Quarterly Journal of Economics, 93/3, 433-446.

[4] Auerbach, A.J. (2002), Taxation and corporate financial policy, in Auerbach, A.J. and M. Feldstein (eds.), Handbook of Public Economics, Vol. 3, Amsterdam: North-Holland.

[5] Auerbach, A.J., M. P. Devereux and H. Simpson (2010), Taxing corporate income, in: James A. Mirrlees, Stuart Adam, Timothy Besley, Richard Blundell, Steve Bond, Robert Chote,

\footnotetext{
${ }^{44}$ This captures the scenario that shareholders will find a replacement for the manager when negotiations break down. The replacement runs the firm possibly at a reduced firm value due to the specificity of the manager's human capital. Alternatively, we may also assume that the manager is indispensable to the firm, i.e., $\bar{U}^{S}=0$. In either case, the tax term $1-\tau^{D}$ factors out the difference $E\left(U^{S}\right)-\bar{U}^{S}$.
} 
Malcolm Gammie, Paul Johnson, Gareth D. Myles, and James Poterba, eds., Dimensions of Tax Design: the Mirrlees Review, Oxford University Press, chapter 9.

[6] Auerbach, A.J. and K.A. Hasset (2002), On the marginal source of investment funds, Journal of Public Economics, 87, 205-232.

[7] Becker, B., M. Jacob and M Jacob (2013), Payout taxes and the allocation of investment, Journal of Financial Economics, 107, 1-24.

[8] Benabou, R. and J. Tirole (2015), Bonus culture: Competitive pay, screening, and multitasking, forthcoming Journal of Political Economy.

[9] Bennedsen, M., F. Pérez-González and M. Wolfenzon (2010), Do CEOs matter?, working paper, Stanford University.

[10] Bertrand, M. and S. Mullainathan (2003), Enjoying the quiet life? Corporate governance and managerial preferences. Journal of Political Economy, 111, 1043-1075.

[11] Berzins, J., Ø. Bøhren and B. Stacescu (2014), Dividend, taxes, and agency costs, CCGR Working Paper 2/13.

[12] Besley, T. and Ghatak (2013), Bailouts and the optimal taxation of bonus pay, American Economic Review: Papers \& Proceedings, 103, 163-167.

[13] Bloom, N. and J. Van Reenen (2010), Human resource management and productivity. In: Ashenfelter, O. and D. Card (eds.), Handbook of Labor Economics. Handbooks in Economics, 4B.

[14] Boadway, R. and N. Bruce (1984), A general proposition on the design of a neutral business tax, Journal of Public Economics, 24, 231-239.

[15] Blouin, J., Raedy, J.S. and D.A. Shackelford (2011), Dividends, share repurchases and tax clienteles: Evidence from the 2003 reductions in shareholder taxes, Accounting Review, 86, 887-914.

[16] Bradford, D. F. (1981), The incidence and allocation effects of a tax on corporate distributions, Journal of Public Economics, 15, 1-22.

[17] Brown, J., N. Liang and S. Weisbenner (2007), Executive financial incentives and payout policy: Firm responses to the 2003 dividend tax cut, Journal of Finance, 62, 1935-1965.

[18] Chetty, R. and E. Saez (2005), Dividend taxes and corporate behavior: Evidence from the 2003 dividend tax cut, Quarterly Journal of Economics, 120, 791-833.

[19] Chetty, R. and E. Saez (2010), Dividend and corporate taxation in an agency model of the firm, American Economic Journal: Economic Policy, 2, 1-31.

[20] Crocker, K.J. and J. Slemrod (2005), Corporate tax evasion with agency costs, Journal of Public Economics, 89, 1593-1610. 
[21] Desai, M., A. Dyck, and L. Zingales (2007), Theft and taxes, Journal of Financial Economics, 84, 591-623.

[22] Desai, M. and D. Dharmapala (2006), Corporate tax avoidance and high-powered incentives, Journal of Financial Economics, 79, 145-179.

[23] Desai, M. and A.D. Goolsbee (2004) Investment, overhang and tax policy, Brookings Papers on Economic Activity, 2, 285-355.

[24] Devereux, M.P. and H. Freeman (1991), A general neutral profits tax, Fiscal Studies, 12, $1-15$.

[25] Gordon, R. and M. Dietz (2009), Dividends and taxes, in: Auerbach, A. and D. Shaviro (Eds.), Institutional Foundations of Public Finance: Economic and Legal Perspectives, Harvard University Press, Cambrdige, MA.

[26] Gordon, R. and J. Slemrod (2000): Are "real" responses to taxes simply income shifting between corporate and personal tax base? In: J. Slemrod (Ed.), Does Atlas shrug? The economic consequences of taxing the rich, Cambridge: Harvard University Press. Russell Sage Foundation, 240-288.

[27] Guner, N., A. Parkhomenko and G. Ventura (2015), Managers and productivity differences, mimeo.

[28] Hall, B.J. and J.B. Liebman (2000), The taxation of executive compensation, in: Poterba, J. (Ed.), Tax Policy and the Economy, 14, 1-44.

[29] Holmstrom, B. (1979), Observability and moral hazard, Bell Journal of Economics, 10, 74-91.

[30] Institute for Fiscal Studies (1991), Equity for Companies: A Corporation Tax for the 1990s, London.

[31] Jacob, M., R. Michaely and A. Alstadsæter (2015), Taxation and dividend policy: The muting effect of diverse ownership structure, Working Paper, WHU.

[32] Jensen, M.C. (1986), Agency costs of free cash flow, corporate finance, and takeovers, American Economic Review, 76, 323-329.

[33] Kanniainen, V. (1999), Failures in corporate governance: Can the corporation tax improve efficiency?, Finanzarchiv, 56, 310-334.

[34] Kanniainen, V. and J. Södersten (1994), Costs of monitoring and corporate taxation, Journal of Public Economics, 55, 307-321.

[35] King, M. (1974), Dividend behaviour and the theory of the firm, Economica, 41, 25-34.

[36] Kleven, H., C. Landais, E. Saez and E. Schultz (2014), Migration and Wage Effects of Taxing Top Earners: Evidence from the Foreigners' Tax Scheme in Denmark, Quarterly Journal of Economics, 129, 333-378. 
[37] Koethenbuerger, M. and M. Stimmelmayr (2014), Managerial incentives and corporate deductibility provisions, Journal of Public Economics, 111, 120-130.

[38] Korinek, A. and J. E. Stiglitz (2009), Dividend taxation and intertemporal tax arbitrage, Journal of Public Economics, 93, 142-159.

[39] Lindhe, T. and J. Södersten (2014), Dividend taxation and the cost of new share issues, CESifo Working Paper 5001, Munich.

[40] Lucas, Jr. R. (1978), On the size distribution of business firms, Bell Journal of Economics, $9,508-523$.

[41] Malmendier, U. and G. Tate (2005), CEO overconfidence and corporate investment, Journal of Finance, 60, 2661-2700.

[42] Murphy, K. (1999), Executive compensation, in Ashenfelter, O. and D. Card (Eds.), Handbook of Labor Economics, Vol. 3, North-Holland, Amsterdam.

[43] Osborne, M. and A. Rubinstein (1990), Bargaining and Markets, Academic Press, London.

[44] Piketty, T., E. Saez and S. Stantcheva (2014), Optimal taxation of top labor incomes: a tale of three elasticities, American Economic Journal: Economic Policy, 6, 230-271.

[45] Poterba, J. (2004), Corporate payout policy, American Economic Review, 94, 171-175.

[46] Poterba, J. and L. Summers (1985), The economic effects of dividend taxation, in: E. Altman and M. Subrahmanyam (Eds.), Recent Advances in Corporation Finance, Dow Jones-Irwin, Homewood, IL, 227-284.

[47] Saez E., J. Slemrod, and S. Giertz (2012), The elasticity of taxable income with respect to marginal tax rates: A critical review, Journal of Economic Literature, 50, 3-50.

[48] Sinn, H.-W. (1987), Capital Income Taxation and Resource Allocation, North-Holland, Amsterdam.

[49] Slemrod, J. (1995), Income creation or income shifting? Behavioral responses to the Tax Reform Act of 1986, American Economic Review, 85, 175-180.

[50] Tirole, J. (2006), The Theory of Corporate Finance, Princeton University Press, Princeton.

[51] Yagan, D. (2015), Capital tax reform and the real economy: The effects of the 2003 dividend tax cut, NBER Working Paper 21003, Cambridge, MA. 